\title{
Analisis Penerapan Pembelajaran Tatap Muka Terbatas di SDIT Luqman Al
}

\section{Hakim Sleman}

\author{
Wildan Nuril Ahmad Fauzi, Yuli Setiawati, Oyib Sulaeman \\ Universitas Islam Negeri Sunan Kalijaga, Yogyakarta, Indonesia \\ Institut Agama Islam Latifah Mubarokiyah, Tasikmalaya, Indonesia \\ wildannufa12@gmail.com
}

\begin{abstract}
ABSTRAK
Penelitian ini termasuk penelitian kualitatif dengan menggunakan metode deskriptif, Teknik pengumpulan data digunakan berupa observasi dan diperkuat dengan kegiatan wawancara dan studi dokumentasi. Pelaksanaan Pembelajaran Tatap Muka Terbatas di SDIT Luqman Al Hakim Sleman dilakukan terlebih dahulu dengan mensosialisasikan kepada orang tua murid dan memberikan surat persetujuan antara sekolah dan orang tua murid. SDIT Luqman Al Hakim Sleman menggunakan Hybrid Learning dalam pelaksanaan Pembelajaran Tatap Muka Terbatas. Adapun PTMT di SDIT Luqman Al Hakim Sleman meliputi: mempersiapkan kurikulum, jam pembelajaran juga dirubah, tetap social distanding, mengatur jarak tempat duduk peserta didik minimal 1 meter, selalu memakai masker, pembelajaran ini hanya dilaksanakan di dalam ruangan saja, saat pembelajaran new normal jam istirahat pun juga ditiadakan, menyemprotkan disinfektan ke setiap penjuru ruang, dalam pembelajaran Tatap Muka Terbatas antara pendidik dengan siswa, siswa satu dengan siswa lainnya tidak boleh saling bersentuhan. Sekolah memberikan tempat untuk mencuci tangan beserta sabunnya, seluruh orang di lingkungan sekolah tanpa terkecuali harus dalam keadaan sehat, baik dari kepala sekolah, pendidik, pegawai dan siswa.
\end{abstract}

Kata Kunci: Pembelajaran, Tatap Muka Terbatas

\section{Analysis of the Application of Limited Face-to-Face Learning at SDIT Luqman Al Hakim Sleman}

\begin{abstract}
This research includes qualitative research using descriptive methods, data collection techniques are used in the form of observations and strengthened by interview activities and documentation studies. The implementation of Limited Face-to-Face Learning at SDIT Luqman Al Hakim Sleman is carried out first by socializing to the parents of students and providing letters of approval between the school and the parents of students. SDIT Luqman Al Hakim Sleman uses Hybrid Learning in the implementation of Limited Face-to-Face Learning. The PTMT at SDIT Luqman Al Hakim Sleman includes: preparing the curriculum, learning hours are also changed, staying socially standardized, adjusting the distance of learners' seating at least 1 meter, always wearing a mask, this learning is only carried out indoors only, when new normal learning rest hours are also eliminated, spraying disinfectant to every corner of the room, in Limited Face-to-Face learning between educators and students, Students should not touch each other. The school provides a place to wash hands and soap, everyone in the school environment without exception must be in good health, both from the principal, educators, employees and students.
\end{abstract}


Keywords: Learning, Limited Face-to-Face

\section{PENDAHULUAN}

Pandemi Covid-19 sudah berlangsung di Indonesia sejak awal 2020 hingga saat ini dan menjadikan berbagai kebiasaan dalam dunia pendidikan di Indonesia berubah. Kegiatan Belajar Mengajar (KBM) sebelum pandemi secara umum dilakukan di sekolah menggunakan berbagai fasilitas dan sumber belajar yang tersedia di sekolah. Seluruh siswa dan guru dapat bertemu secara tatap muka setiap hari aktif dalam seminggu. Namun, setelah datang pandemi Covid-19, pertemuan tersebut tidak bisa dilakukan di sekolah. Menteri Pendidikan dan Kebudayaan menetapkan kebijakan Pendidikan dalam masa darurat penyebaran Covid-19 yaitu salah satunya tentang perubahan proses pembelajaran dari tatap muka menjadi Pembelajaran Jarak Jauh (PJJ) dengan memenuhi ketentuanketentuan tertentu (Kemdikbud RI, 2020).

Pembelajaran jarak jauh menjadi alternatif pemerintah, sehingga siswa diwajibkan belajar dari rumah dengan bimbingan orang tua dibawah koordinasi guru (Aswat et al. 2021). Hal ini tentu tetap menjadi tanggungjawab guru dalam memantau perkembangan belajar siswanya baik secara kognitif, afektif, maupun psikomotoriknya. Hasil kajian (Basar et al. 2021) membuktikan bahwa pembelajaran jarak jauh (PJJ) di masa pandemi covid-19 ini menimbulkan berbagai tanggapan dan perubahan pada sistem belajar yang dapat mempengaruhi proses pemebelajaran serta tingkat perkembangan peserta didik dalam merespon materi yang disampaikan. (Habibah et al. 2020) mengemukakan bahwa untuk mengefektifkan proses pembelajaran yang dilakukan maka dapat memanfaatkan tekhnologi media pembelajaran yang berbentuk platform seperti Google classroom, E-learning, Youtube, WAG, Edmodo, Zoom, Googlemeet dan platform lainnya. Namun bukan berarti pelaksanaan pembelajaran jarak jauh terlaksana dengan baik, dan Kekurangan Pembelajaran Online yaitu Kelebihan pembelajaran online kebebasan ekspresi dari peserta didik, eketifitas waktu dan tempat. Kekurangan pembelajaran online tidak semua peserta didik memiliki tingkat kepahaman yang sama. Bagi sekolah dalam menjalankan pembelajaran online membutuhkan perlatan dan teknis seperti computer, paket data. (Wildan, 2020)

Permasalahan lainnya pun muncul selama pelaksanaan pembelajaran jarak jauh, sehingga kualitas pendidikan di Indonesia dinilai mengalami penurunan dibandingkan dengan negara-negara lainnya, selama pandemic covid-19. Untuk itu pemerintah mulai mengatur strategi agar pembelajaran dapat dilaksanakan secara tatap muka. sehingga muncullah kebijakan baru tentang pelaksanaan pembelajaran tatap muka terbatas yang dibuka mulai juli 2021 dengan ketentuan seluruh tenaga kependidikan telah melakukan vaksinasi dan pembelajaran dilakukan dengan membatasi jam pertemuan, serta penerapan protokol Kesehatan yang ketat. Sehingga dalam hal ini, siswa dibagi 
kedalam kelompok belajar atau dijadwal berdasarkan shift, dengan tujuan membatasi jumlah siswa dalam satu ruangan. (Pattanang, Limbong, and Tambunan 2021)

Perencanaan pembelajaran tatap muka perlu memperhatikan beberapa hal yang dapat di lakukan sekolah anatara lain: 1) Melakukan vaksinasi kepada seluruh pendidik dan tenaga kependidikan yang ada di sekolah; 2) Meningkatkan imun peserta didik, pendidik dan tenaga kependidikan; 3) Mempersiapkan sarana dan prasarana yang sesuai protokol kesehatan. Sebelum diterapkannya pembelajaran tatap muka terbatas, kemdikbud telah mensosialisasikan dan menerbitkan buku panduan pembelajaran masa pandemic. (Kemdikbud 2020) Peran tim pembelajaran, diantaranya 1) melakukan pembagian kelompok belajar dan pengaturan jadwal pelajaran untuk setiap kelompok; 2) melakukan pengaturan tata letak ruangan; 3) memberikan batas pemisah dan penanda arah jalur koridor dan tangga; 4) menerapkan mekanisme pencegahan perundungan bagi warga satuan pendidikan yang terstigma covid-19; 5) menyiapkan seluruh peralatan penerapan protokol Kesehatan.

Pelaksanaan tatap muka ini menerapkan prinsip kehati-hatian karena berkaitan dengan kesehatan dan keselamatan warga sekolah, sehingga protokol Kesehatan wajib diterapkan secara ketat sesuai dengan aturan pelaksanaan tatap muka terbatas. Pembelajaran tatap muka terbatas merupakan pembatasan jumlah peserta didik dalam satu kelas, sehingga perlu mengatur jumlah dengan system rotasi dan kapasitas 50\% dari jumlah siswa pada normalnya, persetujuan orang tua siswa, penerapan protokol Kesehatan yang ketat, tenaga kependidikan telah melakukan vaksinasi, serta sarana dan prasaran pendukung pelaksanaan protocol Kesehatan tersedia.

PTM terbatas berlangsung selama 3 jam pelajaran untuk 1 shift, dan mengombinasikan dengan PJJ, sehingga PTM dilaksanakan 2 sampai 3 kali dalam 1 minggu. Setiap siswa melakukan PTM sebanyak 6 sampai 9 jam dengan sistem masuk dibuat selang seling dengan jeda beberapa menit, agar tidak terjadi penumpukan antara siswa yang akan pulan dan yang akan memasuki ruang kelas. Kondisi ini berdampak bagi guru dan siswa. Dampak bagi guru yaitu; 1) guru kesulitan mengelola pembelajaran dan cenderung focus pada penuntasan kurikulum, 2) waktu pembelajaran berkurang, sehingga guru tidak mungkin memenuhi beban jam mengajar. Sedangkan dampak bagi siswa yaitu; 1) siswa mengalami pengurangan interaksi sosial dengan teman-temannya, 2) mengeluhkan beratnya penugasan dari guru. 3) peningkatan rasa stress dan jenuh karena pembatasan aktivitas selama berada di sekolah, 4) pembelajaran didominasi oleh guru karena penyampaian materi yang cukup padat.

Penelitian (Nissa and Haryanto 2020) menemukan fakta bahwa Guru menghadapi beberapa masalah yang dialamai diantaranya: keterbatasan waktu pembelajaran, dan teknis pelaksanaan pembelajaran yang masih rancu. Namun dengan demikian, kegiatan belajar sudah melibatkan 
interaksi langsung antara siswa dan guru secara tatap muka dan selebihnya dilakukan secara daring. Dengan demikian, penelitian ini bermaksud untuk menganalisis sejauh mana keberhasilan pelaksanaan pembelajaran tatap muka terbatas di SDIT Luqman Al Hakim Sleman, sehingga memperoleh gambaran untuk dapat dijadikan sebagai rujukan dan bahan perbaikan selanjutnya bagi sekolah selama adaptasi PTM terbatas.

\section{METODE PENELITIAN}

Jenis penelitian ini termasuk penelitian kualitatif dengan menggunakan metode deskriptif, penelitian kualitatif merupakan suatu metode berganda dalam fokus, yang melibatkan suatu pendekatan interpretatif dan wajar terhadap setiap pokok permasalahannya (Rahmat, 2019). Metode deskriptif adalah suatu bentuk penelitian yang ditujukan untuk mendeskripsikan fenomenafenomena yang ada, baik fenomena alamiah maupun fenomena buatan manusia (Linarwati et al., 2016). Penelitian ini dilaksanakan di SDIT Luqman Al Hakim Sleman. Teknik pengumpulan data digunakan berupa observasi terkait kegiatan pelaksanaan Pembelajaran Tatap Muka Tervatas diperkuat dengan kegiatan wawancara dan studi dokumentasi (Sugiyono, 2012). Uji validitas data berupa triangulasi sumber setelah penulis membandingkan data yang diperoleh dari sumber berbeda (Basrowi, 2008). Sedangkan Teknik analisis data yang digunakan meliputi reduksi data, penyajian data dan penarikan kesimpulan (Sugiyono, 2018)

\section{HASIL DAN PEMBAHASAN}

Dalam melaksanakan kegiatan belajar pada saat new normal ini, maka pemerintah sudah menyusun protokol penerapan proses pembelajaran pada saat new normal. Oleh karena itu, pihak lembaga harus mempersiapkan beberapa hal dalam melaksanakan pembelajaran di new normal ini. Berikut ini adalah protokol yang sudah disusun pemerintah guna melaksanakan pendidikan di era new normal ini, diantaranya: (Huda, 2020) Pertama, Pembaharuan berbagai data kesiapan sekolah di daerah harus melaksanakan peraturan kesehatan pada saat new normal. Agar bisa melaksanakannya, maka pihak pemerintah tersebut harus melakukan koordinasi bersama pemerintah daerah. Kedua, Pemerintah wajib melaksanakan pengadaan rapid test bagi guru serta petugas-petugas di sekolah. Hal ini dilaksanakan guna memastikan tidak adanya penularan mata rantai virus covid-19. Ketiga, Pemerintah wajib memastikan terkait kesiapan semua struktur dan fasilitas sekolah. Hal ini dikarenakan agar penyesuaian pola pembelajaran yang ada tersebut sesuai dengan protokol kesehatan covid-19 pada saat new normal.

Diterapkannya pembelajaran new normal di Indonesia ini tentunya banyak yang menuai pro dan kontra dimana para masyarakat secara terus-menerus mendesak pemerintah agar segera dilaksanakannya pembelajaran new normal, namun untuk menuju pembelajaran new normal 
diperlukan perencanaan yang sangat matang. Jika pelaksanaan berhasil maka akan sangat berpengaruh pada tingkat kecerdasan peserta didik, akan tetapi jika gagal akan lebih berdampak pada penyebaran virus covid-19 yang nantinya semakin parah. Dengan demikian dari pemerintah sendiri menghimbau kepada para masyarakat meskipun akan diterapkan pembalajaran new normal tidak lupa tetap mematuhi protokol kesehatan yang ketat.(Sugawara and Nikaido, 2014).

Seperti yang terjadi di SDIT Luqman Al Hakim Sleman bahwasannya dalam mempersiapkan pembelajaran menuju new normal ada beberapa hal, diantaranya seperti strategi apa yang akan disiapkan baik dari lembaga pendidikannya maupun dari para pendidiknya. Selain strategi, yang paling utama dipersiapkan adalah tetap mematuhi aturan kesehatan. Dikarenakan pembelajaran secara tatap mukaini dilaksanakan di Era new normal maka protokol disini lebih diutamakan dan diperketat, seperti yang disampaikan oleh Ustad Novi Afriadi Selaku Kepala Sekolah SDIT Luqman Al Hakim Sleman melalui wawancara bahwa sebelum pelaksanaan pembelajaran Tatap Muka Terbatas dilaksanakan, sekolah lebih dulu mensosialisasikan kepada wali murid terkait teknis pelaksanaan kegiatan ini, kemudian sekolah megajak orang tua murid untuk memberikan kesepakatan dengan membuat surat persetujuan untuk mengikuti kegiatan Pembelajaran Tatap Muka Terbatas.

Sekolah juga mempersilahkan keputusan orang tua murid yang tidak menginginkan anaknya untuk mengikuti kegiatan ini atau dengan kata lain mengikuti pembelajaran secara online. Sehingga dalam kegiatan Pembelajaran Tatap Muka Terbatas ini tidak memaksa kehendak orang tua yang tidak menginginkan kegiatan ini. Ustad Novi A friadi juga mengemukakan bahwa SDIT Luqman Al Hakim Sleman menggunakan Hybrid Learning dalam pembelajaran, menurut Ustad Novi Hybrid learning menjadi solusi terbaik dalam pembelajaran, dengan menggunakan aturan khusus dimana jumlah siswa dibatasi dengan Sebagian menjalani pembelejaran jarak jauh dan sebagian masuk kelas, dan juga menerapkan protokol Kesehatan.

Hybrid learning adalah pembelajaran yang memadukan antara kegiatan pembelajaran tatap muka dengan pembelajaran berbasis teknologi computer dan internet (Galus et al., 2021). Hybrid learning memfasilitasi siswa mendapatkan bahan-bahan untuk kegiatan pembelajaran melalui internet. Guru juga dapat memantau kegiatan siswa melalui internet. Menurut Husamah (2014), hybrid learning merupakan pembelajaran yang menggabungkan berbagai cara penyampaian, model pengajaran, serta berbagai media teknologi yang beragam. Hybrid learning adalah pembelajaran kolaborasi yang sangat efektif untuk diterapkan di dalam kelas (Singh, 2003). Selain itu menurut Widana (2020), hybrid leraning bukan hanya mengurangi jarak yang selama ini ada diantara siswa 
dan guru namun juga meningkatkan interaksi di antara kedua belah pihak. Berdasarkan definisi tersebut dapat kita simpulkan bahwa hybrid learning merupakan penggabungan antara belajar online dengan pembelajaran tatap muka biasa. Hanya saja dalam penerapannya perlu adanya penyesuaian, yang mana tergantung kondisi sekolah dan tempat tinggal siswa (Setyo, 2021)

Pelaksanaan Tatap Muka Terbatas yang dilaksanakan oleh SDIT Luqman Al Hakim Sleman tentunya telah memiliki izin dari Dinas Pendidikan Sleman, dan juga telah mempersiapkan Teknis dan Pedoman kegiatan Tatap Muka Terbatas, dengan menggunakan metode Hybrid Learning maka peserta didik dapat mengikuti pembelajaran setiap harinya secara offline dan juga online. Berikut ini prosedur pelaksanaan Pembelajaran Tatap Muka Terbatas SDIT Luqman Al Hakim Sleman:

1. Pertama, pada aspek pembelajaran di SDIT Luqman Al Hakim Sleman mempersiapkan kurikulum dengan semaksimal mungkin mengikuti anjuran pemerintah dimana selama pandemi covid-19, dengan menyajikan kompetensi dasar dari materi esensial. Maksudnya adalah menentukan materi yang dasar dan dianggap penting untuk dipahami atau dikuasai oleh peserta didik, kemudian menyusun struktur dan jadwal sesuai kurikulum darurat, serta menentukan standar kompetensi lulusan yang realistis sesuai dengan kondisi pandemi.

2. Selain menentukan kurikulum, jam pembelajaran juga dirubah, setiap pararel mulai dari kelas satu sampai enam telah dibuatkan jadwal untuk melaksanakan pembelajaran Tatap Muka Terbatas di sekolah. Peserta didik di bagi mejadi dua kelompok setiap kelasnya dengan penentuan ganjil genap melalui nomor presensi dalam pembagian siswa dengan kapasitas kelas 50\% setiap pekannya. Pembelajaran setiap harinya durasi 2 jam.

3. Ketiga, meskipun pembelajaran tatap muka ini dilaksanakan secara tatap muka tidak lupa tetap social distanding seperti mengatur jarak tempat duduk peserta didik minimal 1 meter. Agar peserta didik tidak teledor dan paham akan situasi darurat maka bisa diberi pembatas atau tanda. Peserta didik meskipun dikelas rendah maupun kelas tinggi harus paham bahwa mereka harus menjaga jarak dengan teman sekelasnya. Kemudian peserta didik yang bukan jadwalnya untuk melaksanakan PTM maka mengikuti kegiatan melalui platfrom google meet atau zoom seperti gambar berikut ini:

\section{Gambar 1: Pelaksanaan kegiatan pembelajaran Hybrid Learning SDIT Luqman Al}

\section{Hakim Sleman}




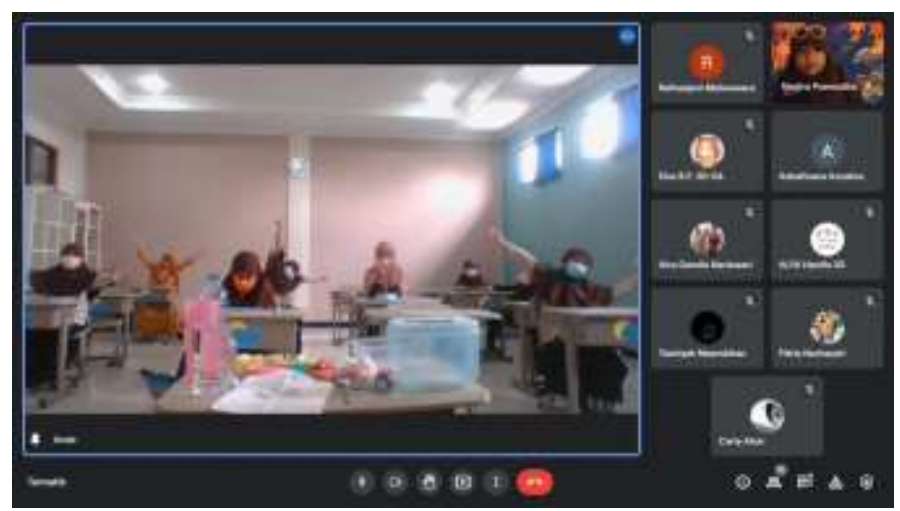

4. Keempat, selalu memakai masker dan atau faceshield, selama pembelajaran berlangsung guru maupun peserta didik tidak diperkenankan memakai masker tapi di tarik kebawah sampai ke dagu, terlebih lagi tidak boleh membuka masker sama sekali.

5. Kelima, pembelajaran ini hanya dilaksanakan di dalam ruangan saja, materi pelajaran yang biasanya membutuhkan sarana perpustakaan dan laboratorium ditiadakan untuk sementara. Guru hanya boleh mengajar di satu kelas saja tidak diperkenakan pindah ruang kelas.

Gambar 2: Pelaksanaan kegiatan pembelajaran di ruang kelas SDIT Luqman Al Hakim Sleman

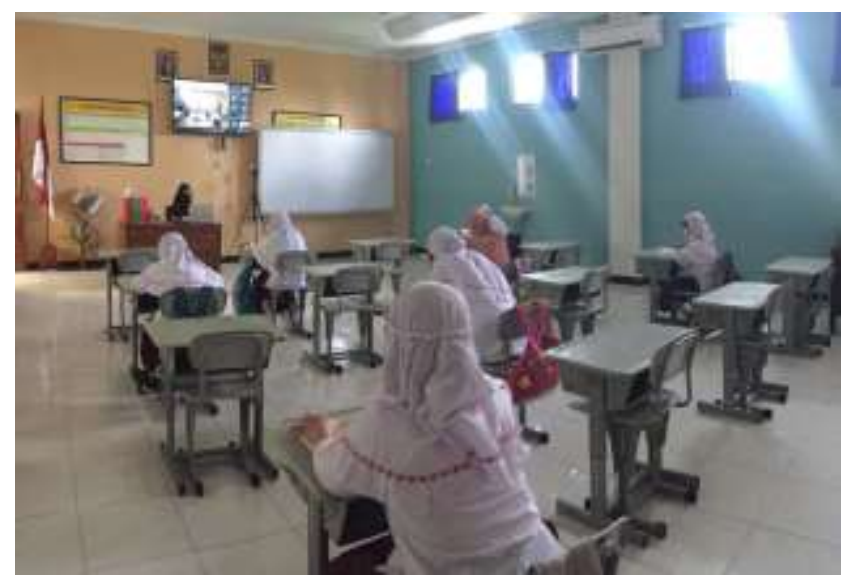

6. Keenam, saat pembelajaran new normal jam istirahat pun juga ditiadakan. Peserta didik diarahkan guru agarmembawa makanan dari rumah masing-masing, agar peserta didik ketika makan ataupun minum dalam wadah yang sudah pasti steril dari rumah.

7. Ketujuh, Setiap pagi dan sepulang siswa dari sekolah, sekolah selalu menyemprotkan disinfektan ke setiap penjuru ruang, misalnya ruang kepala sekolah, ruang guru, kamar mandi, ruang kelas, dan ruang lainnya agar dipastikan setiap harinya selalu steril.

8. Kedelapan, dalam pembelajaran Tatap Muka Terbatas antara pendidik dengan siswa, siswa satu dengan siswa lainnya tidak boleh saling bersentuhan.

9. Kesembilan, Sekolah memberikan tempat untuk mencuci tangan beserta sabunnya dengan air yang mengalir di setiap penjuru ruang dan dalam jumlah yang cukup. 
10.Kesepuluh, seluruh orang di lingkungan sekolah tanpa terkecuali harus dalam keadaan sehat, baik dari kepala sekolah, pendidik, pegawai dan siswa. Selalu memakai masker selama disekolah. Sebelum memasuki gerbang sekolah satpam disekolah harus mengecek suhu tiap orang. Jika suhu melewati 37,3 derajat maka tidak diperkenakan masuk lingkungan sekolah. Kesebelas, rapat guru ataupun rapat walimurid diadakan secara daring untuk menghindari kerumunan

Kelebihan dari sistem ini adalah dengan metode Hybrid Learning ini proses belajar mengajar dua kelompok siswa ini ternyata lumayan efektif, sekolah tidak perlu menjadwal terpisah antara kelompok siswa yang hadir di sekolah dengan yang belajar dari rumah. Kelebihan lainnya dari sistem ini adalah interaksi antara guru dan siswa yang hadir dalam proses belajar mengajar kembali dapat diterapkan. Hal ini membuat guru lebih mudah memantau perkembangan akademis peserta didiknya. Dengan metode ini, guru juga mempunyai kesempatan untuk kembali menjelaskan materi di depan kelas dengan segala perlengkapan yang bisa mendukung berkembangnya daya tangkap siswa, dibandingkan dengan metode Pembelajaran Jarak Jauh yang hanya menggunakan PowerPoint, video pembelajaran, serta layar perangkat lunak yang terbatas.

Selain membahas kelebihan dari sistem Hybrid Learning ini, tentunya penting juga untuk membahas kelemahan dari sistem ini sehingga di kemudian hari dapat kita perbaiki bersama. Kelemahan yang paling signifikan terlihat adalah masalah penyediaan perangkat pendukung Hybrid Learning yang harganya masih tergolong besar. Selain biaya besar yang diperlukan untuk penyediaan perangkat, juga diperlukan jaringan internet yang stabil. Hal lainnya adalah guru masih sulit memantau perkembangan akademis siswa yang memilih belajar daring. Peserta didik yang memilih belajar daring pun berkecenderungan mengalami menurunnya semangat belajar dan rasa tanggung jawabnya. Dampaknya akan terjadi kesenjangan dalam proses penyerapan ilmu antara siswa yang hadir di kelas dengan yang di rumah.

\section{SIMPULAN}

Dalam melaksanakan kegiatan belajar pada saat new normal pemerintah sudah menyusun protokol penerapan proses pembelajaran pada saat new normal Pertama, Pembaharuan berbagai data kesiapan sekolah Kedua, Pemerintah wajib melaksanakan pengadaan rapid test bagi guru serta petugas-petugas di sekolah Ketiga, Pemerintah wajib memastikan terkait kesiapan semua struktur dan fasilitas sekolah.

Pelaksanaan Pembelajaran Tatap Muka Terbatas di SDIT Luqman Al Hakim Sleman dilakukan terlebih dahulu dengan mensosialisasikan kepada orang tua murid dan memberikan surat persetujuan antara sekolah dan orang tua murid. SDIT Luqman Al Hakim Sleman menggunakan Hybrid Learning dalam pelaksanaan Pembelajaran Tatap Muka Terbatas. Adapun PTMT di SDIT Luqman Al Hakim Sleman meliputi: mempersiapkan kurikulum, jam pembelajaran juga dirubah, tetap social distanding, mengatur jarak tempat duduk peserta didik minimal 1 meter, selalu memakai masker, pembelajaran ini hanya dilaksanakan di dalam ruangan saja, saat pembelajaran new normal 
jam istirahat pun juga ditiadakan, menyemprotkan disinfektan ke setiap penjuru ruang, dalam pembelajaran Tatap Muka Terbatas antara pendidik dengan siswa, siswa satu dengan siswa lainnya tidak boleh saling bersentuhan. Sekolah memberikan tempat untuk mencuci tangan beserta sabunnya, seluruh orang di lingkungan sekolah tanpa terkecuali harus dalam keadaan sehat, baik dari kepala sekolah, pendidik, pegawai dan siswa.

\section{DAFTAR PUSTAKA}

Ahmad Fauzi, Wildan Nuril., Munastiwi Erni,. 2020. “Analisis Proses Pembelajaran Berbasis Online Masa Pandemi Covid-19 di SDIT Luqman AL-Hakim Sleman”. El-Hikmah: Jurnal Kajian dan Penelitian Pendidikan Islam. Vol. 14, No. 2. 171-186.

Aswat, Hijrawatil Et Al. 2021. "Implikasi Distance Learning Di Masa Pandemi COVID 19 Terhadap Kecerdasan Emosional Anak Di Sekolah Dasar.” Jurnal Basicedu 5(2): 761-71.

Basar, Afip Miftahul Et Al. 2021. "Problematika Pembelajaran Jarak Jauh Pada Masa Pandemi Covid-19 (Studi Kasus Di SMPIT Nurul Fajri - Cikarang Barat - Bekasi ) A . Pendahuluan Kemampuan, Sikap, Dan Bentuk-Bentuk Tingkah Laku Yang Bernilai Positif . Hal Itu Untuk Pencipta . Pendidikan S.” 2(1): 208-18

Basrowi. 2008. Memahami Penelitian Kualitatif. Rineke Cipta

Galus, S.A., Arifin, \& Sulkifly. 2021. Kesiapan sekolah dalam pengelolaan model pembelajaran hybrid learning di SMA kota Gorontalo. Student Journal of Educational Management, 1(1), 41-56

Habibah, Riasatul Et Al. 2020. "Pemanfaatan Teknologi Media Pembelajaran Di Masa Pandemi Covid-19.’’Trapsila: Jurnal Pendidikan Dasar 2(02): 1.

Husamah. 2014. Pembelajaran bauran (blended learning). Prestasi Pustakarya

Kemdikbud RI. 2020. Panduan Pembelajaran Jarak Jauh. Kementrian Pendidikan Dan Kebudayaan, 021, 28. https://bersamahadapikorona.kemdikbud.go.id/panduan-pembelajaran-jarak-jauh/

Kemdikbud. 2020. "Panduan Penyelenggaraan Pembelajaran Di Masa Pandemi COVID-19." Kemendikbud 2019: 1-58. Https://Www.Kemdikbud.Go.Id/Main/Blog/2020/06/BukuSaku-Panduan-Pembelajaran-Di-Masa-Pandemi-Covid19.

Linarwati, M., Fathoni, A., \& Minarsih, M. M. (2016). Studi Deskriptif Pelatihan Dan Pengembangan Sumberdaya Manusia Serta Penggunaan Metode Behavioral Event Interview Dalam Merekrut Karyawan Baru Di Bank Mega Cabang Kudus. Journal of Management, 2(2), 1

Pattanang, Emik, Mesta Limbong, And Witarsa Tambunan. 2021. "Perencanaan Pelaksanaan Pembelajaran Tatap Muka Di Masa Pandemi Pada Smk Kristen Tagari." Jurnal Manajemen Pendidikan 10(2): 112-20.

Rahmat, P. S. (2019). Penelitian Kualitatif. Equilibrium, 5(9). https://doi.org/10.31227/osf.io/wtncz

Setyo, D. 2021. Model-model pembelajaran hybrid (seri 3 hybrid learning). Tersedia pada http://dedysetyo.net/2021/01/02/model-model-pembelajaran-hybrid-seri-3-hybridlearning/. Diakses tanggal 14 Oktober 2021. 
Singh, H. 2003. Building effective blended learning programs. Issues of Educational Technology, 43(6), 51-54

Sugiyono. 2018. Metode Penelitian Pendidikan: Pendekatan Kuantitatif, kualitatif dan R\&D. Alfabeta.

Widana, I. W. \& Septiari, L. K. 2021. Kemampuan berpikir kreatif dan hasil belajar matematika siswa menggunakan model pembelajaran Project- Based Learning berbasis pendekatan STEM. Jurnal Elemen, 7(1), 209-220. https://doi.org/10.29408/jel.v7i1.3031 